\title{
Tourism CSR Model during the COVID-19 Pandemic: Literature Review
}

\author{
Rahesli Humsona ${ }^{1 *}$, Mahendra Wijaya ${ }^{1}$, Drajat Tri Kartono ${ }^{1}$, and Agung Wibowo ${ }^{1}$ \\ ${ }^{1}$ Post Graduate Programme, Universitas Sebelas Maret, Surakarta, Indonesia
}

\begin{abstract}
This research aims to study the potential development of tourism Corporate Social Responsibility (CSR) model during COVID-19 pandemic, through creating framework of tourism CSR model compatible to increase the tourist visit rate. Research method employed was literature review with qualitative approach. The result of research showed COVID-19 pandemic condition conceived through risk society theory. Theoreticians raised reflexivity concept to see abilities of responding to and anticipating risk. CSR is a business policy guiding company to integrate social and environmental problem into their business vision, mission, and strategy, and their interaction with stakeholders. Strategy development and CSR implementation are intended to identify and to manage stakeholders' expectation. Tourism CSR model during COVID-19 pandemic can be developed based on stakeholder reflexivity, offering 5 stages: identify learning goals, focus on specific problem at work, reflect on personal predispositions, learn about learning, and develop reflexivity. Stakeholder analysis generates basic dimensions of advantage and perceived threat, perceived social impact, guidance value and principle, guideline of ethical decision making, and stakeholders' information need. Stakeholder reflexivity can result in decision to revise more health protocol-oriented program. Image as a safe destination will increase the tourist visit.
\end{abstract}

\section{Introduction}

Society and the corporation are closely related. Corporation is a part of society and interacts with various groups within society. Society can enjoy advances because of industrialization done by corporations. They produce a variety of daily needs, keep developing, and embody into institutions influencing very dominantly every aspect of social life. Corporation also plays an important role in creating job opportunity, offering wealth, and changing social structure. In contrast, a society that enables business and provides resources like educated and health workers, physical and legal infrastructure, and market for their product [1]. However, the higher number of corporations developing leads to a wider social gap and the damage of the surrounding environment [2,3]. It is this matter that brings out Corporate Social Responsibility (CSR) discourse discussed widely in some studies [4].

\footnotetext{
* Corresponding author: rahesli64@staff.uns.ac.id
} 
The corporation's orientation to profit merely is considered ignoring business ethics. Each corporation is responsible for its business activities and activities affecting, directly or indirectly, the stakeholders where the corporation exists. CSR refers to a concept that business is responsible for the wider society's interest, rather than the organization's financial interest-only [5]. CSR practice indicates a corporation's goodwill to improve the quality of stakeholders' life around the corporation, either internally or externally. CSR activity will contribute positively to creating, improving, and maintaining corporate image [6]. The advantage grows awareness that life sustainability and a corporation's long-term development are dependent on the achievement of balance between profitability and harmony with various stakeholders [7].

Just like other industries, tourism also brings economic and social advantages to destinations. Nevertheless, tourism also can affect negatively economic, social, and environmental aspects [8]. Realizing this, tourism company also takes social responsibility for the natural and social environment where it operates. However, during the crisis due to the COVID-19 pandemic in 2020, many industries go bankrupt. No certain industry is invulnerable to this pandemic, and tourism and hotel industries are the ones affected most adversely [9].

COVID-19 pandemic encourages the companies to prefer deciding the termination of the employment relationship with workers quickly without giving wage, although this choice can decrease corporate credibility. But, at the same time, some companies keep having goodwill and contribution in their way, i.e. disseminating the more meaningful corporate values [10]. This measure was taken by the company realizing that their life sustainability and long-term development are dependent on the achievement of balance between profitability and harmony with various stakeholders [11].

A study on tourism CSR during the COVID-19 pandemic is important to do. Modern tourism history recorded many local crises and some international crises, characterized by the extreme and sudden decrease of demand for tourist destinations or certain tourism product type [12]. Crisis is a non-natural and social disaster that can threaten human life [13]. Society dysfunction is a serious disruption harmful to human life, whether materially, economically, or environmentally.

Until the time when this research was conducted, it cannot be ascertained when this COVID-19 pandemic will end. The pandemic condition has led to the decrease in tourist number so that CSR's vision and mission were also putatively adjusted with the attempt of increasing the number of visitors. This research aims to study the potential development of the tourism Corporate Social Responsibility (CSR) model during COVID-19 pandemic. The research tries to create the framework of tourism CSR model compatible to increase the number of visitors to tourist destinations.

\section{Methodology}

This study employed a literature review method adopting a qualitative approach (metasynthesis) $[14,15]$. The procedure of research started with identifying a research problem, developing research protocol, determining database of searching location, selecting relevant thinking (books) and research products (journals and proceedings), selecting quality thinking and research products, synthesizing thinking and research products, and displaying the result of research. The procedure of activities is organized in the table below. 
Table 1. The Procedure of Literature Review Activities.

\begin{tabular}{|c|c|c|}
\hline No & Process Stages & Objective \\
\hline 1 & Identifying research problem & Transforming problem into the research problem \\
\hline 2 & $\begin{array}{c}\text { developing research protocol of } \\
\text { literature review: introduction, } \\
\text { theory, method, result, discussion, } \\
\text { and conclusion }\end{array}$ & Guiding the literature review process \\
\hline 3 & $\begin{array}{c}\text { Determining location and database } \\
\text { of thinking (books) and research } \\
\text { products (journals and } \\
\text { proceedings) as the searching area }\end{array}$ & $\begin{array}{c}\text { Limiting the searching area to relevant thinking } \\
\text { and research products: web of science, google } \\
\text { scholar, researchgatenet, sciencedirect.com, } \\
\text { scimago.com, doaj.org }\end{array}$ \\
\hline 4 & $\begin{array}{c}\text { Selecting relevant thinking and } \\
\text { research products: theory and } \\
\text { model }\end{array}$ & $\begin{array}{c}\text { Collecting thinking and the research products } \\
\text { relevant to research question }\end{array}$ \\
\hline 5 & $\begin{array}{c}\text { Selecting quality thinking and } \\
\text { research products }\end{array}$ & $\begin{array}{c}\text { Excluding and including the thinking and research } \\
\text { products into literature review by quality }\end{array}$ \\
\hline 6 & $\begin{array}{c}\text { Extracting data from individual } \\
\text { studies }\end{array}$ & $\begin{array}{c}\text { Extracting data from individual study to get } \\
\text { important finding }\end{array}$ \\
\hline 7 & $\begin{array}{c}\text { Synthesizing the result using the } \\
\text { meta-synthesis (narrative) method }\end{array}$ & $\begin{array}{c}\text { Synthesizing the result using meta-synthesis } \\
\text { (narrative technique) }\end{array}$ \\
\hline 8 & Displaying the result & $\begin{array}{c}\text { Writing the result of research with literature } \\
\text { review into the article }\end{array}$ \\
\hline
\end{tabular}

\section{Results and Discussion}

\subsection{Results}

\subsubsection{Risk society}

Society amid Covid-19 pandemic time can be conceived using risk society theory [16]. Risk social refers to a modern society life that is entering new modernity. Its difference from the old one is characterized by the management of power and wealth with its distribution. The challenge now is the risk and how to prevent it by orienting mainly to security and safety.

Beck explains that modernization is in direct contact with industrial and risk societies. Industrial society has a commodity distribution principle, while the principle of risk society is the distribution of bad things. Beck explains risk as potential physical, mental, and social damages due to technological processes and other social life processes.

This shift can be characterized by the people's understanding of disaster, starting with some disasters caused by community activities, the impact of which is unpredictable and likely unknown. The concept of risk is bound to reflexive modernity [17], how the risk is hindered, minimized, or distributed. It is important for the risk society to cope with or to minimize the problems to occur in life.

Citing Beck, Piliang mentions that there are 3 (three) risk types [18]: physical-ecological risk, social risk, and mental (psyche) risk. Whatever the type, risk and class are two inseparable things. Risk occurs in both upper and lower classes of society. Therefore, the risk cannot remove the class society but instead strengthens it. The distribution of risk is inherent inversely to the class pattern. Wealth accumulates in the upper social layer, while the risk is instead inherent to the lower-social layer. The upper class of society can avoid the risk, while the lower one becomes the object of risk [19]. To reduce the risk encountered by those in the 
lower class, goodwill is expected to come from the corporation to undertake moral obligation and to implement its social contribution to the society through the CSR program.

\subsubsection{Stakeholders of Tourism CSR}

CSR is closely related to stakeholders. The term stakeholder was first coined by Edward Freeman, as an individual or a group that can affect or be affected by the various corporate decisions, policy or operations [20]. If classified, according to Jones [21], the stakeholder is composed of inside stakeholders, namely those having interest and demand for a corporate resources and existing within the corporate organization. They are shareholder/stockholders, managers, and employees. It is also composed of outside stakeholders, i.e. constituencies that are not owners, leaders, or employees of the company, but have an interest in the company and are affected by corporate decisions and actions. They are customers, suppliers, government, local communities, and general public.

Stakeholder theory is based on how to observe, identify, and explain analytically a variety of elements underlying decision making and action in running business activity. Then, the mapping was conducted on the relationship established in business activity. Generally, it is conducted as an attempt of showing whoever has an interest, is related to, and participating in business activity in general [22].

Different businesses of the company will lead to different stakeholder priorities. Society and the surrounding environment are stakeholders in the priority scale to the mining companies. Meanwhile, consumers are the first-priority stakeholders to the consumer good company [23].

Rhenald Kasali, as cited in Wibisono [24], illustrates the interrelationship between the company and stakeholders in the stakeholders map model, representing the diversity of parties interested in the company. Each of them has different interest types and levels about the companies, so that they have different expectations and satisfaction with the company.

\subsection{Discussion}

Safety and health orientation that can restrain people from doing mobility contribute to the decrease in the number of tourist visits. To improve the number of tourist visits, the CSR model needed is to create a safe tourist destination. From the literature study, it can be found 2 (two) important concepts to develop the tourism CSR model: reflexivity and stakeholder. Reflexivity is the concept suggested by Beck when offering risk society theory [25]. The stakeholder concept suggested by Durlacher is related to CSR in tourism [26]. Also, from literature study 2 (two) CSR management models are found using the 2 (two) keywords. Firstly, Reflexivity: Linking Individual and Organizational Values [27]. Secondly, A Stakeholder Model for Emerging Technologies [28]. The tourism CSR model during the pandemic was developed by trying to combine the two models.

The reflexivity model builds on-premise that it is not appropriate to assign responsibility to organization as if the organization has personality. The decision is not made by the organization but by people within it. Personal values are the filter creating an individual's interpretation of organizational policy and decision. Reflexivity suggested by Beck points to personal reflexivity in which the mature members of modern society question life patterns and social (moral) values. Social values underlie the way risk is hindered, minimized, or distributed. It is important for risk society to cope with and to minimize the problem to occur in life.

The stakeholder model for technology offers stakeholder analysis in organizations intended to implement CSR particularly about new and developing technology. This focus is very important, recalling the development of environmental management and information 
technology, and the wish to balance ethical, social, and cultural effects and commercial factors sustainably [29].

The stakeholder can be adopted to deal with the worsening situation by creating new technology or way. This model can analyze the appropriate stakeholder in CSR activity during the COVID-19 pandemic, consisting of employees, formal and informal leaders, tourism performers related to transportation, accommodation, and destination, people living in the tourism areas, and tourists.

From the two models, a tourism CSR model can be developed based on stakeholder reflexivity. The reflexivity model offers 5 (five) stages of reflexivity [30]: identify learning goals, focus on the specific problems at work, reflect on personal predispositions, learn about learning, and develop reflexivity. These stages are applied to tourism CSR stakeholders. The stakeholder model for technology can be adopted because the health protocol norm to prevent the transmission also needs the use of new technology and improves the developing technology. Tourism CSR model during COVID-19 pandemic consists of some basic dimensions [31]: advantage and perceived threat, perceived social impact, guidance value and principle, the guideline of ethical decision making, and stakeholders' information need (see fig.1). Stakeholder reflexivity can result in the decision to revise the more health protocol-oriented program. The implementation of the tourism CSR program by prioritizing health protocol can build an image as a safe destination, and thereby can increase the number of tourists. 


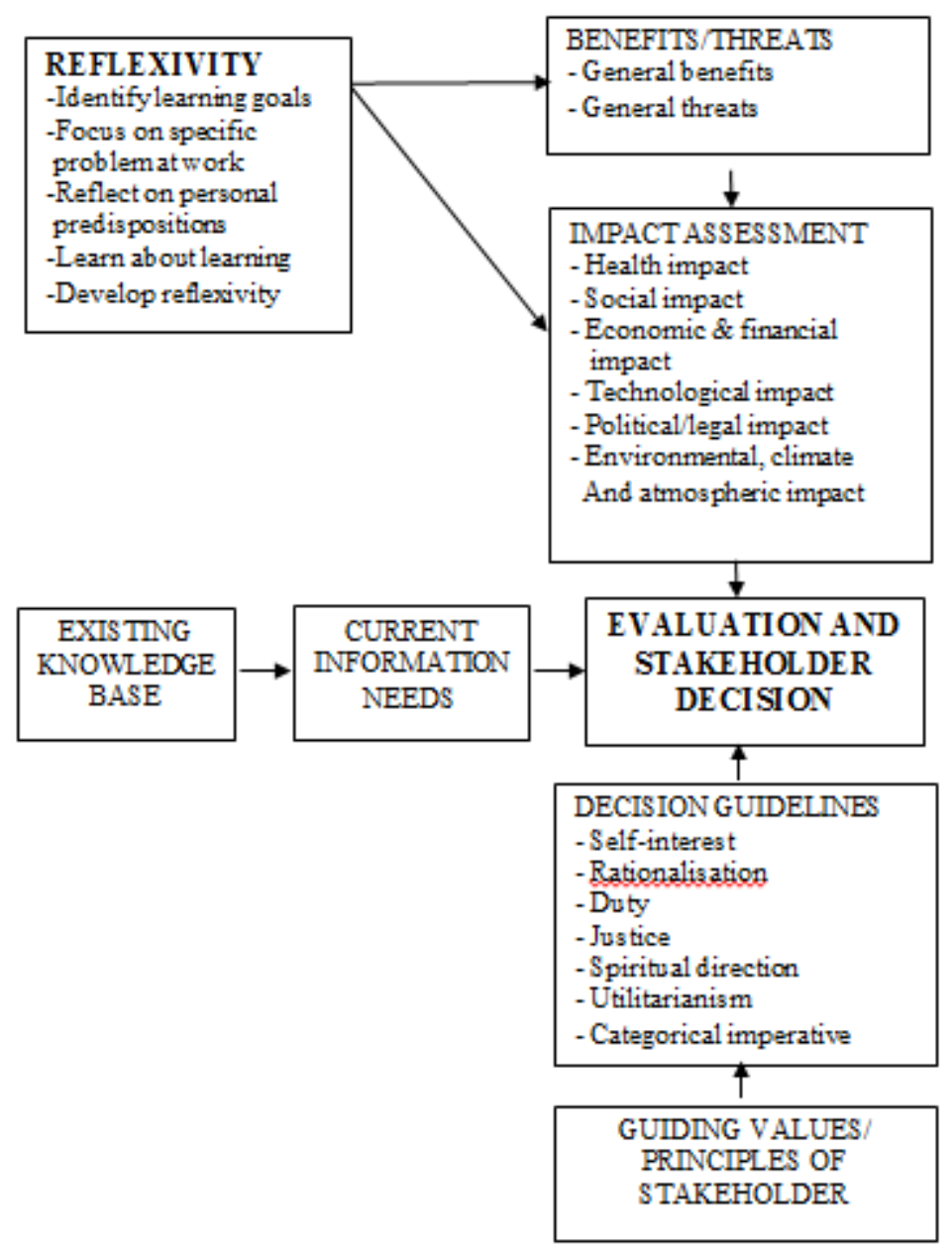

Fig. 1. A Tourism CSR Model Based on Stakeholder Reflexivity.

\section{Conclusion}

It is still unpredictable when the COVID-19 pandemic condition will end. The tourism industry is mostly affected by it is required to keep having social responsiveness to the condition of society through CSR programs. The tourism company needs CSR model corresponding to the COVID-19 pandemic condition. The tourism CSR model based on stakeholder reflexivity is oriented to increasing the number of tourists.

The stakeholder of tourism CSR consists of the company's employees, formal and informal leaders, tourism performers related to transportation, accommodation, and destination, people living in the tourism area, and tourists. Stakeholder reflexivity can result in the decision to revise the more health protocol-oriented program. The stakeholder's social practice in implementing the tourism CSR program can build an image as a safe destination, so that can increase the number of tourists. 


\section{References}

1. D.L. Durlacher, Corporate social responsibility (University Vienna, 2018)

2. Y. Sopyan, Corporate social responsibility (CSR) sebagai implementasi fikih sosial untuk pemberdayaan masyarakat, Ahkam, 14, 1 (2014)

3. M. Aryawan, I. K. Rahyuda, N. W. Ekawati, Pengaruh faktor CSR (aspek sosial, ekonomi dan lingkungan) terhadap citra perusahaan, E-JMU, 6, 2 (2017)

4. R. Kanji, R Agrawal, Models of corporate social responsibility: comparison, evolution and convergence, IIM KSM, 5, 2 (2016)

5. I.M.G. Sanches, Corporate social responsibility during COVID-19 pandemic, ITMC, 126, $6(2020)$

6. A. Triana, S. Sulastri, S. Humaedi, Ragam praktik CSR selama pandemi Covid-19, In Proceeding of Penelitian dan Pengabdian kepada Masyarakat, 7, 2 (2020)

7. H. He, L. Harris, The Impact of Covid-19 pandemic on corporate social responsibility and marketing philosophy, JBR, 116, May (2020)

8. D. L. Durlacher, Corporate social responsibility (University Vienna, 2018).

9. S. Lee, Corporate social responsibility and Covid-19: research implication, TEJ, 20, 10, (2020)

10. L. A. Anwar, Pandemi membuat perusahaan memikirkan kembali pola CSR, (August, 2020), Retrieved from https:/www.kompas.id/baca/metro/2020/04/29/pandemimembuat-perusahaan-memikirkan-kembali-pola-csr/

11. H. He, L. Harris, The Impact of Covid-19 pandemic on corporate social responsibility and marketing philosophy, JBR, 116, (2020)

12. E. Laws, B. Prideaux, K. Chon, Crisis management in tourism, (Athenaeum Press Gateshead, 2007)

13. B. Faulker, Towards a Framework for Tourism Disaster Management, TM, 22, 2 (2001)

14. A. Perry, N. Hammond, N, Systematic review: The Experience of a PhD student, Psychology Learning and Teaching, 2, 1 (2002)

15. Siswanto, Systematic review sebagai metode penelitian untuk mensintesis hasil-hasil penelitian (sebuah pengantar), BPSK, 13, 4, (2010)

16. U. Beck, Masyarakat Risiko menuju modernitas baru, (Kreasi Wacana Yogyakarta, 2015)

17. R. Sutopo, Transisi pemuda dalam masyarakat risiko: antara aspirasi, hambatan dan ketidakpastian, JUP, 11, 3 (2014)

18. Y.A. Piliang, Humanity: risiko tinggi, (Rumah Wacana, 2009)

19. G. Ritzer, D. J. Goodman, Teori sosiologi modern, (Kencana Press Jakarta, 2005)

20. R.E. Freeman, Strategic management: a stakeholder approach (Pitman Publishing London, 1984)

21. T.M. Jones, Instrumental stakeholder theory - a synthesis of ethics and economics, AMR, 20, 2 (1995)

22. I. Wahyudi, B. Azheri, Corporate social responsibility: prinsip, pengaturan dan implementasi, (Inspire Malang, 2008)

23. Y. Wibisono, Membedah konsep dan aplikasi CSR, (Ashkaf Media Grafika Surabaya, 2007)

24. R. Kasali, Manajemem periklanan, konsep dan aplikasinya di Indonesia (2007)

25. U. Beck, Masyarakat risiko menuju modernitas baru, (Kreasi Wacana Yogyakarta, 2015)

26. D.L. Durlacher, Corporate social responsibility (University Vienna, 2018)

27. N. Osborne, M. Redfern, Reflexivity: Linking individual and organizational values (Radboud University Nijmegen, 2006) 
28. G.M. McDonald, D. Rolland, A Stakeholder model for emerging technologies (Radboud University Nijmegen, 2006) 